\title{
ОРГАНІЗАЦІЙНО-ЕКОНОМІЧНИЙ
} МЕХАНІЗМ СТИМУЛЮВАННЯ РОЗВИТКУ СФЕРИ ТУРИЗМУ, КУРОРТІВ ТА ГОТЕЛЬНОГО ГОСПОДАРСТВА

\section{Сергій Захарін}

Доктор економічних наук, старший науковий співробітник;

ORCID: 0000-0002-1263-8170; e-mail: z0679330105@gmail.com

Київський національний університет культури і мистецтв, Київ, Україна

\section{Анотація}

Проаналізовано стан та динаміку розвитку сфери туристичних послуг України, а також наведено оцінку основним явищам і процесам, виявлено ключові тенденції розвитку цього ринку. Вказано, що недостатній рівень розвитку інфраструктури, невідповідність закладів розміщення світовим стандартам, технологічна відсталість туристичних операторів, недосконалість нормативно-правового забезпечення туристичної та курортної діяльності стримує розвиток у сфері туризму і курортів. Через коливання рівня реальних доходів населення на ринку туристичних послуг спостерігаються тотожні процеси і у платоспроможності попиту, що ускладнює планування діяльності підприємств туристичної, готельної та курортної діяльності. Зроблено висновок, що вказані причини виключають зміцнення інвестиційної привабливості об'єктів туристичної інфраструктури, а відтак - і належну конкурентоспроможність усієї туристичної сфери. Описано окремі аспекти механізму державної підтримки розвитку сфери туризму в Україні. Показано чинники формування туристичного потенціалу України. Обґрунтовано пріоритетні напрями державної політики стимулювання розвитку туризму. Внесено пропозиції щодо удосконалення інструментів підтримки розвитку сфери туризму.

Ключові слова: туризм; сфера туризму; туристична діяльність; державна політика у сфері туризму; державна підтримка розвитку туризму

\section{Вступ}

Актуальність проблеми в загальному вигляді та їі зв'язок з важливими науковими чи практичними завданнями. Україна має розвинутий туристичний потенціал, що створює певні умови для стійкого розвитку туристично-курортного господарства та туристичної інфраструктури. Однак, вказаний потенціал використовується недостатньо ефективно. В Україні, за висновком фахівців, сфера туризму, курортів та готельного господарства генералізує біля 1\% валового внутрішнього продукту, в той час як у світі цей показник дорівнює 8\%, а в окре- 
мих країнах - 12-15\%. В таких умовах, на нашу думку, регулюючі органи мають вжити заходів щодо розробки та запровадження дієвих інструментів державної підтримки розвитку туризму та об'єктів туристичної інфраструктури.

Розвиток стимулює реалізацію інвестиційних проектів із розбудови готельно-туристичної, ресторанної та транспортної інфраструктури, що каталізує економічне зростання та підвищення якості життя місцевого населення. Отже, державна підтримка розвитку туризму та об'єктів туристичної інфраструктури, за своїм економічним змістом, $є$ одним із напрямів державної соціально-економічної політики.

\section{Аналіз останніх досліджень}

Проблеми розвитку сфери туризму України, посилення позитивного впливу на вказаний розвиток економічних чинників, визначення перспективних важелів підтримки функціонування туристичної інфраструктури досліджуються у працях провідних науковців: М. Ю. Барни та І. І. Тучковської (2016), В. Г. Герасименка та С. С. Галасюк (2008), С. В. Захаріна (2002), М. В. Субботи (2012, 2013), Т. І. Ткаченко (2009) та інші. Зокрема, ученими розроблено методологію формування пріоритетів державної політики у сфері туризму, проаналізовано умови сталого розвитку сфери туризму, узагальнено міжнародний досвід активізації розвитку туристичної діяльності. Проте, в сучасних умовах, які характеризуються розбалансованістю економічної системи, виникають нові ризики: об'єктивна неможливість здійснення державної підтримки функціонування туристичної інфраструктури, а також звуження попиту (внаслідок зменшення реальних доходів населення). За таких обставин, погодимося з думкою, що існує необхідність поглибленого дослідження та виділення напрямів реформування механізму державної підтримки розвитку сфери туризму в Україні в сучасних умовах, а також виявлення перспектив та можливих векторів зростання зазначеної сфери.

Постановка завдання (формулювання цілей статті). Мета статті - подати результати досліджень із виявлення проблем та перспектив розвитку сфери туризму і курортів в Україні.

\section{Виклад основного матеріалу}

Україна має розвинутий туристичний потенціал (природні об'єкти, рекреаційні ресурси, вигідне економіко-географічне положення, курортні бази та ін.), що створює певні умови для стійкого розвитку туристично-курортного господарства та туристичної інфраструктури. Однак, в Україні сфера туризму, курортів та готельного господарства не відіграє належної ролі у формуванні макроекономічних показників. Відтак, виникає потреба у розробці механізмів стимулювання розвитку сфери туризму та туристичної діяльності.

Протягом 2004-2018 рр. затверджено низку законодавчих та інших нормативно-правових актів, що регулюють діяльність підприємств сфери туризму і курортів, у тому числі: туроператорів, турагентів, санаторно-курортних 
закладів, оздоровчих закладів, підприємств готельного господарства та ін. Зокрема, ухвалено Закони України «Про туризм» та «Про курорти». Згідно статті 6 Закону України «Про туризм» (Верховна Рада України, 1995), держава проголошує туризм одним з пріоритетних напрямів розвитку економіки та культури і створює умови для туристичної діяльності. Законодавець у частині четвертій зазначеної статті проголосив такі цілі державного регулювання в галузі туризму:

- забезпечення закріплених Конституцією України прав громадян на відпочинок, свободу пересування, відновлення і зміцнення здоров'я, на безпечне для життя і здоров'я довкілля, задоволення духовних потреб та інших прав;

- безпека туризму, захист прав та законних інтересів туристів, інших суб'єктів туристичної діяльності та їх об'єднань, прав та законних інтересів власників або користувачів земельних ділянок, будівель та споруд;

- збереження цілісності туристичних ресурсів України, їх раціональне використання, охорона культурної спадщини та довкілля, врахування державних і громадських інтересів при плануванні та забудові територій;

- створення сприятливих умов для розвитку індустрії туризму, підтримка пріоритетних напрямів туристичної діяльності.

Основними пріоритетними напрямами державної політики в галузі туризму визначено (Барна \& Тучковська, 2016):

- удосконалення правових засад регулювання відносин у галузі туризму;

- забезпечення становлення туризму як високорентабельної галузі економіки України, заохочення національних та іноземних інвестицій у розвиток індустрії туризму, створення нових робочих місць;

- розвиток в'їзного та внутрішнього туризму, сільського, екологічного (зеленого) туризму;

- розширення міжнародного співробітництва, утвердження України на світовому туристичному ринку; створення сприятливих для розвитку туризму умов шляхом спрощення та гармонізації податкового, валютного, митного, прикордонного та інших видів регулювання;

- забезпечення доступності туризму та екскурсійних відвідувань для дітей, молоді, людей похилого віку, осіб з інвалідністю та малозабезпечених громадян шляхом запровадження пільг стосовно цих категорій осіб.

у частині другій статті 6 Закону України «Про туризм» (Верховна Рада України, 1995) вказано, що реалізація державної політики в галузі туризму здійснюється шляхом:

- визначення і реалізації основних напрямів державної політики в галузі туризму, пріоритетних напрямів розвитку туризму;

- визначення порядку класифікації та оцінки туристичних ресурсів України, їх використання та охорони;

- спрямування бюджетних коштів на розробку і реалізацію програм розвитку туризму;

- визначення основ безпеки туризму;

- нормативного регулювання відносин у галузі туризму(туристичного, готельного, екскурсійного та інших видів обслуговування громадян); 
- ліцензування в галузі туризму, стандартизації туристичних послуг, визначення кваліфікаційних вимог до посад фахівців туристичного супроводу;

- встановлення системи статистичного обліку і звітності в галузі туризму та курортно-рекреаційного комплексу;

- організації і здійснення державного контролю за дотриманням законодавства в галузі туризму;

- визначення пріоритетних напрямів і координації наукових досліджень та підготовки кадрів у галузі туризму;

- участі в розробці та реалізації міжнародних програм з розвитку туризму.

У статті 12 Закону України «Про туризм» (Верховна Рада України, 1995) задекларовано, що для забезпечення охорони туристичних ресурсів України, їх збереження та відновлення, раціонального використання, забезпечення безпеки туризму, конституційних прав громадян на відпочинок та інших прав громадян, патріотичного виховання органами державної влади та органами місцевого самоврядування, в межах їх повноважень, затверджуються державні цільові, регіональні та інші програми розвитку туризму. Програми розвитку туризму затверджуються з метою реалізації довгострокових пріоритетів країни в галузі туризму і становлять комплекс взаємопов'язаних правових, економічних та організаційних заходів, спрямованих на реалізацію конституційних прав громадян, розвиток туристичної галузі. Державні цільові регіональні та інші програми розвитку туризму повинні передбачати заходи щодо забезпечення безпеки в галузі туризму.

У затвердженій Урядом Концепції Державної цільової програми розвитку туризму та курортів на період до 2022 року недостатню увагу приділено застосуванню сучасних економічних інструментів розвитку курортів та курортних територій. У запропонованій програмі не вжито понять: «курорт», «курортна територія», «курортна діяльність», «курортне господарство», «курортні послуги», «курортний ринок» (Субота, 2012). За висновком фахівців, визначені авторами Концепції варіанти розв'язання проблемних питань $€$ декларативними і не відповідають вимогам законодавчих та інших нормативно-правових актів (Барна \& Тучковська, 2016). У Концепції лише фрагментарно вказано очікувані результати виконання Державної цільової програми розвитку туризму та курортів на період до 2022 року.

Таким чином, в Україні створено базові умови нормативно-методичного регламентування економічної діяльності у сфері туризму і курортів.

Однак, зафіксовані офіційною статистикою тенденції розвитку сфери туризму, курортів та готельного господарства вказують на значну волатильність динаміки функціонування суб'єктів туристичного ринку. За даними Держстату, у 2018 р. в Україні туристичну діяльність здійснювали 1833 суб'єкти юридичні особи, у тому числі 529 туроператорів, 1243 турагентів та 61 суб'єкт екскурсійної діяльності. Окрім того, туристичну діяльність здійснювали 2460 фізичних осіб - підприємців. Усього у туристичній і курортній галузях України нараховується понад 6 тис. підприємств, з яких понад 1,2 тис. готелів, близько 1,1 тис. інших об'єктів розміщення. Показники розвитку туристичного бізнесу за 2017-2018 рр. наведено у таблиці 1. 
Таблиця 1

Показники розвитку туристичного бізнесу (юридичні особи)

\begin{tabular}{|l|c|c|c|c|}
\hline \multirow{2}{*}{\multicolumn{1}{|c|}{ Показники }} & \multicolumn{2}{|c|}{2017} & \multicolumn{2}{c|}{2018} \\
\cline { 2 - 5 } & усього & $\begin{array}{c}\text { у тому числі } \\
\text { туроператори }\end{array}$ & усього & $\begin{array}{c}\text { у тому числі } \\
\text { туроператори }\end{array}$ \\
\hline $\begin{array}{l}\text { Кількість суб'єктів } \\
\text { туристичної діяльності, од. }\end{array}$ & 1743 & 498 & 1833 & 529 \\
\hline $\begin{array}{l}\text { Середньооблікова кількість } \\
\text { штатних працівників, осіб }\end{array}$ & 8190 & 4638 & 8934 & 4809 \\
\hline $\begin{array}{l}\text { Дохід від надання туристичних } \\
\text { послуг (без врахування } \\
\text { непрямих податків), млрд. грн }\end{array}$ & 18,5 & 17,9 & 21,1 & 20,3 \\
\hline $\begin{array}{l}\text { Сума комісійних, агентських } \\
\text { і інших винагород, млрд. грн. }\end{array}$ & 0,7 & 0,3 & 1,0 & 0,3 \\
\hline $\begin{array}{l}\text { Операційні витрати на надання } \\
\text { туристичних послуг, млрд. грн. }\end{array}$ & 14,9 & 14,2 & 17,9 & 17,1 \\
\hline
\end{tabular}

Складено за даними Держстату («Туристична діяльність в Україні у 2018 році», 2019).

Кількість суб'єктів туристичної діяльності у 2018 р. порівняно з 2017 р., як свідчать дані таблиці 1, зросла з 1743 од. до 1833 од., тобто на 90 од., або на 5,2\%. Відповідно, зростали показники середньооблікової кількості штатних працівників (на 9,1\%), отриманого доходу від надання туристичних послуг (на 14,1\%) та ін. Це вказує на зростання ємності ринку туристичних послуг в Україні у 2018 р., що є закономірним наслідком зростання платоспроможного попиту на туристичні продукти. В свою чергу, зростання платоспроможного попиту на туристичні продукти пояснюється зростанням реальних доходів населення, а також, в деякій мірі, лібералізацією візового режиму (зокрема, з Китайською Народною Республікою), що приваблює іноземних туристів.

Збільшення обсягу наданих туристичних послуг суб'єктами туристичної діяльності зумовлено, зокрема, підвищенням вартості одного туро-дня (через інфляцію) та подовженням тривалості подорожі (внаслідок зростання запитів «організованих туристів» до якості туристичного обслуговування) (Герасименко \& Галасюк, 2008).

Аналіз статистичних даних дає змогу зробити висновок, що туристичні потоки протягом 2000-2007 рр. збільшувалися. Це пояснюється, у першу чергу, зростанням реальних доходів громадян. У 2008-2009 рр. було зафіксовано деякий спад туристичних потоків, натомість, починаючи з 2010 р., знову спостерігалося збільшення. У 2016-2018 рр. також відбувалося збільшення туристичного потоку (без урахування тимчасово окупованих територій). В той же час із вказаними тенденціями не корелюють обсяги туристів, обслугованих туроператорами та турагентами (тобто, так звані «організовані туристи»). Приміром, у 2004-2005, 2010 та 2015 рр. кількість туристів зростала, натомість, кількість «організованих туристів» - зменшувалася («Туристична діяльність в Україні у 2018 році», 2019). Це пов'язано із зростанням обізнаності населення у здійс- 
ненні туристичних формальностей, а також у стрімкому зростанні економічного сегменту індустрії подорожувань (усе більша кількість туристів прагне самостійно здійснювати туристичні формальності, включно із бронюванням послуг: засобів розміщення, купівлею квитків, організацією екскурсій тощо).

Проаналізуємо дані туристичних потоків протягом 2010-2018 рр.:

Туристичні потоки, осіб

Таблиця 2

\begin{tabular}{|c|c|c|c|c|c|c|}
\hline \multirow[t]{2}{*}{ Роки } & \multicolumn{2}{|c|}{$\begin{array}{c}\text { Громадян України, } \\
\text { які виїжджали за кордон - } \\
\text { усього }{ }^{2}\end{array}$} & \multicolumn{2}{|c|}{$\begin{array}{c}\text { Іноземці, які відвідали } \\
\text { Україну - усього } 2\end{array}$} & \multicolumn{2}{|c|}{$\begin{array}{c}\text { Туристи, обслуговані } \\
\text { туроператорами } \\
\text { та турагентами - усього }\end{array}$} \\
\hline & $\begin{array}{l}\text { Кількість, } \\
\text { осіб }\end{array}$ & Зростання, \% & $\begin{array}{l}\text { Кількість, } \\
\text { осіб }\end{array}$ & Зростання, \% & $\begin{array}{c}\text { Кількість, } \\
\text { осіб }\end{array}$ & Зростання,\% \\
\hline 2010 & 17180034 & 108,2 & 21203327 & 104,8 & 2280757 & 107,2 \\
\hline 2011 & 19773143 & 115,1 & 21415296 & 101,0 & 2199977 & 96,5 \\
\hline 2012 & 21432836 & 108,4 & 23012823 & 107,5 & 3000696 & 136,4 \\
\hline 2013 & 23761287 & 110,9 & 24671227 & 107,2 & 3454316 & 115,1 \\
\hline $2014^{1}$ & 22437671 & 94,4 & 12711507 & 51,5 & 2425089 & 70,2 \\
\hline $2015^{1}$ & 23141646 & 103,1 & 12428286 & 97,8 & 2019576 & 83,3 \\
\hline $2016^{1}$ & 24668233 & 106,6 & 13333096 & 107,3 & 2549606 & 126,2 \\
\hline $2017^{1}$ & 26437413 & 107,2 & 14229642 & 106,7 & 2806426 & 110,1 \\
\hline $2018^{1}$ & н. д. & н. д. & н. д. & н. д. & 4557447 & 162,4 \\
\hline
\end{tabular}

Складено та розраховано за даними Держстату («Туристична діяльність в Україні у 2018 році», 2019).

Примітки:

1 Дані за 2014-2018 рр. - без урахування тимчасово окупованої території Автономної Республіки Крим, м.Севастополя та тимчасово окупованих територій у Донецькій та Луганській областях.

${ }^{2}$ Включно з одноденними відвідувачами (за даними Адміністрації Держприкордонслужби України).

${ }_{3}$ Звітність за 2000-2010 рр. сформовано за даними Міністерства інфраструктури України, починаючи з 2011 року - за даними Держстату.

Наведені дані дають змогу зробити висновок, що протягом 2016-2018 рр. туристичні потоки зросли, що є позитивною тенденцією, оскільки це створює економічне підґрунтя для активізації процесів створення нового та модернізація наявного у туристичній інфраструктурі, а також підвищує інвестиційну привабливість сфери туризму і курортів.

В той же час, слід зазначити, що розвиток офіційного (формального) туристичного ринку залежить від кількості туристів, що отримали послуги у туроператорів та турагентів. Тому необхідно проаналізувати туристичні потоки, що обслуговуються офіційними туроператорами та турагентами. Статистичні дані про кількість туристів, обслугованих туроператорами та турагентами, у розрізі видів туризму, наведено у табл. 3. 
Таблиця 3

\section{Кількість туристів, обслугованих туроператорами та турагентами, за видами туризму, осіб}

\begin{tabular}{|c|c|c|c|c|}
\hline \multirow[b]{2}{*}{ Роки } & \multirow{2}{*}{$\begin{array}{c}\text { Кількість туристів, } \\
\text { обслугованих } \\
\text { туроператорами } \\
\text { та турагентами, усього } 2\end{array}$} & \multicolumn{3}{|c|}{ У тому числі } \\
\hline & & $\begin{array}{c}\text { в'їзні (іноземні) } \\
\text { туристи }\end{array}$ & виїзні туристи & $\begin{array}{c}\text { внутрішні } \\
\text { туристи }\end{array}$ \\
\hline 2000 & 2013998 & 377871 & 285353 & 1350774 \\
\hline 2001 & 2175090 & 416186 & 271281 & 1487623 \\
\hline 2002 & 2265317 & 417729 & 302632 & 1544956 \\
\hline 2003 & 2856983 & 590641 & 344332 & 1922010 \\
\hline 2004 & 1890370 & 436311 & 441798 & 1012261 \\
\hline 2005 & 1825649 & 326389 & 566942 & 932318 \\
\hline 2006 & 2206498 & 299125 & 868228 & 1039145 \\
\hline 2007 & 2863820 & 372455 & 336049 & 2155316 \\
\hline 2008 & 3041655 & 372752 & 1282023 & 1386880 \\
\hline 2009 & 2290097 & 282287 & 913640 & 1094170 \\
\hline 2010 & 2280757 & 335835 & 1295623 & 649299 \\
\hline 2011 & 2199977 & 234271 & 1250068 & 715638 \\
\hline 2012 & 3000696 & 270064 & 1956662 & 773970 \\
\hline 2013 & 3454316 & 232311 & 2519390 & 702615 \\
\hline $2014^{1}$ & 2425089 & 17070 & 2085273 & 322746 \\
\hline $2015^{1}$ & 2019576 & 15159 & 1647390 & 357027 \\
\hline $2016^{1}$ & 2549606 & 35071 & 2060974 & 453561 \\
\hline $2017^{1}$ & 2806426 & 39605 & 2289854 & 476967 \\
\hline $2018^{1}$ & 4557447 & 75945 & 4024703 & 456799 \\
\hline
\end{tabular}

Складено за даними Держстату («Туристична діяльність в Україні у 2018 році», 2019).

\section{Примітки:}

1 Дані за 2014-2018 рр. - без урахування тимчасово окупованої території Автономної Республіки Крим, м. Севастополя та тимчасово окупованих територій у Донецькій та Луганській областях.

${ }^{2}$ Включно з одноденними відвідувачами (за даними Адміністрації Держприкордонслужби України).

Дані таблиці 3 засвідчують, що, протягом 2016-2018 рр., кількість туристів, обслугованих туроператорами та турагентами, зростала, причому аналогічна тенденція зафіксована у сегменті в'їзного та виїзного туризму. У сегменті внутрішнього туризму у 2018 р. зафіксовано падіння кількості туристів, що отримали послуги у туроператорів та турагентів, що пов'язане, на нашу думку, з орієнтацією споживачів на отримання туристичних послуг без звернення до туроператорів та турагентів. 
В той же час стійкий розвиток сфери туризму, курортів та готельного господарства неможливий без належної матеріально-технічної бази (туристичної інфраструктури). Матеріальна-технічна база туристичного ринку характеризується, у першу чергу, наявністю сучасних об'єктів туристичної інфраструктура, ключовим елементом якої є колективні засоби розміщування (готелі, пансіонати тощо). Стан динаміки колективних засобів розміщення характеризують дані таблиці 4.

Таблиця 4

\section{Колективні засоби розміщення ${ }^{1}$}

\begin{tabular}{|c|c|c|c|c|}
\hline \multirow[t]{2}{*}{ Роки } & \multirow{2}{*}{$\begin{array}{c}\text { Кількість колективних } \\
\text { засобів розміщення } \\
\text { (КЗР), од }\end{array}$} & \multirow[t]{2}{*}{ Кількість місць тис. од } & \multicolumn{2}{|c|}{$\begin{array}{c}\text { Кількість осіб, що перебували } \\
\text { у КЗР, тис. }\end{array}$} \\
\hline & & & усього & з них іноземці \\
\hline 2011 & 5882 & 567,3 & 7426,9 & 1427,7 \\
\hline 2012 & 6041 & 583,4 & 7887,4 & 1554,8 \\
\hline 2013 & 6411 & 586,6 & 8303,1 & 1665,1 \\
\hline $2014^{2}$ & 4572 & 406,0 & 5423,9 & 551,5 \\
\hline $2015^{2}$ & 4341 & 402,6 & 5779,9 & 665,8 \\
\hline $2016^{2}$ & 4256 & 375,6 & 6544,8 & 863,7 \\
\hline $2017^{2}$ & 4115 & 359,0 & 6661,2 & 824,5 \\
\hline $2018^{2}$ & 4719 & 300,0 & 7006,2 & 917,9 \\
\hline
\end{tabular}

Складено за даними Держстату («Туристична діяльність в Україні у 2018 році», 2019).

Примітки:

1 Юридичні особи, відокремлені підрозділи юридичних осіб та фізичні особипідприємці.

${ }^{2}$ Без урахування тимчасово окупованої території Автономної Республіки Крим, м. Севастополя та тимчасово окупованих територій у Донецькій та Луганській областях.

Згідно даних таблиці 4, можемо дійти висновку, що динаміка кількості колективних засобів розміщення у 2018 р., порівняно з 2017 р., є позитивною (хоча у 2015-2017 рр. спостерігалося падіння показника), при цьому кількість місць знизилася. Це пов'язано з тенденцією виведення (видалення) аварійних та непридатних приміщеннь, або без належного облаштування, що стало закономірним наслідком підвищення вимогливості споживачів до якості обслуговування. Слід звернути увагу, що показник кількості осіб, які відвідували колективні засоби розміщення, протягом 2015-2019 рр. зростає. В Україні функціонують готелі усіх категорій, у тому числі і готелі категорії «5 зірок». Проте, в цілому матеріально-технічна база підприємств сфери туристичної інфраструктури (готелі та інші засоби розміщення, заклади харчування, заклади санаторно-курортного господарства та ін.) не відповідає світовому рівню (Герасименко \& Галасюк, 2008). Вказане об'єктивно знижує конкурентоспроможність національного туристичного продукту. 
Окремо слід проаналізувати стан та динаміку курортної інфраструктури, яка $є$ доволі розвинутою, оскільки створювалася з орієнтацією на задоволення попиту споживачів із усіх радянських республік. В Україні $є$ усі типи відомих мінеральних лікувальних вод (Субота, 2013, с. 355), також фактично функціонує понад 100 курортів та курортних територій, санаторно-курортні заклади відкрито у всіх регіонах.

Кількість санаторно-курортних закладів (у т. ч. санаторіїв та санаторіївпрофілакторіїв) протягом 2015-2018 рр. скорочується. Не відповідають сучасним стандартам асортимент та якість курортних послуг, які надають більшість санаторно-курортних закладів. Внаслідок відсутності капітальних інвестицій збільшується фізичний та моральний знос лікувального обладнання, що використовується санаторно-курортними закладами (Субота, 2012).

Сектор домогосподарств (населення) в умовах економічної кризи цілком природно скорочує споживання продуктів сфери послуг, у тому числі туристичних та курортних послуг, що і не дивно, оскільки витрати спрямовуються, у першу чергу, на задоволення базових потреб - харчування, купівля одежі та товарів тривалого використання тощо. Відтак, в межах реалізації соціальноекономічної політики, держава (органи державного регулювання) мають вживати заходів, спрямованих на підтримку розвитку сфери туризму і курортів. Органи державної влади та управління, в межах наявних повноважень, намагаються здійснювати стимулювання розвитку сфери туризму, у тому числі туристичної інфраструктури. Однак, на нашу думку, організаційно-економічний механізм державної підтримки розвитку сфери туризму і курортів є недосконалим. Переважна більшість законодавчих норм, що визначають цілі, напрями та механізми державного регулювання у сфері туризму, носять декларативний характер і в умовах української дійсності не створюють бажаних позитивних правових наслідків.

Вважаємо, що негативний вплив на розвиток сфери туризму, курортів та готельного господарства чинять: недостатнє фінансування заходів у сфері некомерційного просування національного туристичного продукту; низька активність українських учасників на міжнародних туристичних виставках (у тому числі через відсутність державної підтримки виставкової діяльності); неефективність системи контролю за туристичною діяльністю із використанням визнаних міжнародних стандартів; відсутність раціональної системи державного управління туризмом у регіонах; недостатній рівень інвестиційного та інноваційного забезпечення розвитку сфери туризму тощо (Барна \& Тучковська, 2016; Захарін, Соболь, \& Мельник, 2013; Ткаченко, 2009). Відтак, необхідна розробка та реалізація комплексних заходів, спрямованих на подолання кризових явищ та інтенсифікації виробництва національного туристичного продукту із забезпеченням належного рівня якості (Захарін \& Байков, 2015). Основою для здійснення таких заходів має стати формування цілеспрямованої державної політики у сфері туризму з визначенням пріоритетів їі розвитку, посилення ефективності залучення економічних інструментів при реалізації механізмів регулювання туристичної діяльності.

На нашу думку, необхідно вжити ефективних заходів організаційноекономічного характеру. Державна підтримка розвитку сфери туризму та курортів, враховуючи особливості об'єкту регулювання, має здійснюватися на ос- 
нові програмно-цільового методу управління, який передбачає розробку Державної цільової комплексної програми із встановленням відповідних критеріїв результативності. Така програма має передбачати реалізацію низки заходів, спрямованих на адаптацію сфери туризму і курортів до наявних викликів, забезпечення гармонійного розвитку туристичного ринку на основі врахування інтересів різних суб'єктів, а також спрямованих на раціональне використання, збереження та примноження національного туристичного потенціалу. Слід проводити роботу з удосконалення адміністрування роботи фондів соціального страхування. Вказане призведе, зокрема, до стимулювання платоспроможного попиту на санаторно-курортні послуги, у тому числі через удосконалення роботи фондів соціального страхування.

Ключовими напрямами державної політики підтримки розвитку сфери туризму мають стати: вдосконалення правових засад регулювання відносин у галузі; забезпечення становлення туризму як високорентабельної галузі економіки України, заохочення національних та іноземних інвестицій у розвиток індустрії туризму, створення нових робочих місць; розвиток міжнародного та внутрішнього туризму, зокрема, сільського та екологічного (зеленого); розширення міжнародного співробітництва, утвердження України на світовому туристичному ринку; створення сприятливих для розвитку туризму умов шляхом спрощення та гармонізації податкового, валютного, митного, прикордонного та інших видів регулювання (Захарін, 2002).

Слід також врахувати, що одним із зовнішньополітичних пріоритетів України є європейська інтеграція. Відтак, державна політика у сфері туризму, згідно нашої думки, повинна базуватися на принципах та стандартах документів ЄС (зокрема, Ради Європи) з питань сталого розвитку туризму. Серед таких документів, що можуть бути імплементовані в Україні, слід виділити: «Генеральний курс для сталого і екологічно-безпечного розвитку туризму», «Політика сталого туризму на природоохоронних територіях», «Політика розвитку сталого та екологічно безпечного туризму на прибережних територіях» (Герасименко \& Галасюк, 2008). Імплементація світових та європейських стандартів розвитку туризму сприятиме створенню належних економічних умов для підтримки сталого розвитку туризму в Україні.

В документах міжнародних організацій сформульовано парадигму так званого «сталого туризму». Сталий туризм - це такий напрям розвитку туризму, який дає можливість задовольняти потреби туристів нині та в майбутньому з урахуванням інтересів регіону, який їх приймає. (Захарін, Соболь \& Мельник, 2013). Концепція сталого розвитку передбачає, що управління наявними в країні ресурсами (у тому числі туристичними) має здійснюватися так, щоб економічні, соціальні та естетичні потреби задовольнялися без порушення культурної та екологічної цілісності, а біологічному різноманіттю та системам життєзабезпечення не було завдано шкоди.

Опрацювання наукових праць (Барна \& Тучковська, 2016; Герасименко \& Галасюк, 2008; Захарін, Соболь \& Мельник, 2013; Субота, 2013; Ткаченко, 2009) дало можливість сформувати рекомендації щодо перспективних організаційноекономічних заходів, спрямованих на підтримку розвитку сфери туризму: 
- широке впровадження програм державно-приватного партнерства у сфері туризму,

- оптимізація структури управління сферою туризму на національному та регіональному рівнях,

- залучення міжнародної технічної допомоги,

- активізація реалізації грантових програм, спрямованих на підтримку та розвиток об'єктів туристичної інфраструктури та об'єктів показу,

- розробка методичних рекомендацій щодо управління сферою туризму на регіональному рівні, у тому числі у малих містах,

- удосконалення механізму контролю у сфері туризму, у тому числі, шляхом впровадження інструментів ліцензування та акредитації підприємств туристичної інфраструктури,

- імплементація документів ЄС у сфері туризму і курортів.

Доцільно розробити та затвердити стратегічні орієнтири розвитку курортів та курортної діяльності, а саме:

- оптимізаціяструктури та режиму функціонування курортно-рекреаційного комплексів, у першу чергу, на курортах державного значення;

- удосконалення структури управління у сфері курортів та курортної діяльності, підвищення результативності координування дій місцевих органів виконавчої влади з цього питання;

- створення привабливого інвестиційного клімату у галузі курортів та курортного господарства;

- забезпечення умов для виконання законодавства про охорону та раціональне використання природно-лікувальних та курортних ресурсів.

Слід вжити невідкладних заходів стимулювання платоспроможного попиту на санаторно-курортні послуги (як з боку корпоративного сектору, так і з боку індивідуальних споживачів). Таке стимулювання можна здійснювати, у тому числі, через удосконалення роботи фондів соціального страхування та збільшення обсягів фінансового ресурсу, що спрямовується на закупівлю путівок на санаторно-курортне та відновлювальне лікування за рахунок коштів фондів соціального страхування.

\section{Висновки}

Обґрунтована доцільність реалізації комплексу заходів щодо подальшого реформування механізму державної підтримки розвитку туризму, у тому числі: широке впровадження програм державно-приватного партнерства у сфері туризму; оптимізація структури управління сферою туризму на національному та регіональному рівнях; залучення міжнародної технічної допомоги; активізація реалізації грантових програм, спрямованих на підтримку та розвиток об'єктів туристичної інфраструктури та об'єктів показу; розробка методичних рекомендацій щодо управління сферою туризму на регіональному рівні, у тому числі, у малих містах; удосконалення механізму контролю у сфері туризму, у тому числі, шляхом впровадження інструментів ліцензування та акредитації підприємств туристичної інфраструктури; імплементація документів ЄС у сфері туризму і курортів. 
Державна підтримка розвитку сфери туризму має здійснюватися на основі програмно-цільового методу управління. Тому доцільно розробити Державну цільову комплексну програму (ДЦКП), встановивши відповідні критерії результативності її реалізації. Вказана програма має передбачати реалізацію низки заходів, спрямованих на стимулювання розвитку сфери туризму, підтримку гармонійного розвитку туристичного ринку, раціональне використання, збереження та примноження національного туристичного потенціалу.

Реформування механізму державної підтримки розвитку сфери туризму має здійснюватися на основі концепції сталого туризму, що визначена у документах міжнародних організацій. Слід здійснити імплементацію ключових документів у сфері управління, що розроблені провідними світовими та європейськими організаціями.

Необхідно вжити заходи із стимулювання платоспроможного попиту на санаторно-курортні послуги, у тому числі, через удосконалення роботи фондів соціального страхування.

У подальшому необхідні дослідження з розробки методичних рекомендацій щодо прогнозування та моделювання параметрів розвитку сфери туризму, курортів та готельного господарства за різними сценаріями.

\section{Список бібліографічних посилань}

Барна, М.Ю., \& Тучковська, І.І. (2016). Основні тенденції управління туристичною діяльністю в Україні. Підприємництво і торгівля, 20, 5-8.

Верховна Рада України. Закон України "Про туризм" № 324/95-ВР від 15.09.1995. Взято з https://zakon.rada.gov.ua/laws/show/324/95-вр.

Герасименко, В.Г., \& Галасюк, С.С. (2008). Управління національним туризмом в контексті міжнародного досвіду. Вісник ДІТБ, 12, 160-167.

Захарін, С.В. (2002). Державне регулювання іноземного інвестування. Фінанси України, 1, 92-101.

Захарін, С.В., \& Байков, М.А. (2015). Формування інтелектуального капіталу як орієнтир управління комерційною діяльністю туристичного підприємства. Молодий вчений, 9, 50-62.

Захарін, С.В., Соболь, В.П., \& Мельник, Ю.Р. (2013). Сталий розвиток сфери туристичних послуг: глобальні тенденції, міжнародна взаємодія, уроки для України. Економічний вісник університету, 20/3, 297-303.

Субота, М.В. (2012). Інноваційні підходи до стимулювання розвитку курортів. Проблеми науки, 12, 28-32.

Субота, М.В. (2013). Стратегічні орієнтири державної політики стимулювання розвитку курортної діяльності. Економічний вісник університету, 20/2, 353-358.

Ткаченко, Т.І. (2009). Сталий розвиток туризму: теорія, методологія, реалії бізнесу [Монографія]. Київ: Київський національний торговельно-економічний університет.

Туристична діяльність в Україні у 2018 році. (2019). Державна служба статистики України. Взято в http://www.ukrstat.gov.ua/operativ/operativ2019/tyr/tyr_dil/arch_tyr_dil.htm. 


\section{References}

Barna, M.Yu., \& Tuchkovska, I.I. (2016). Osnovni tendentsii upravlinnia turystychnoiu diialnistiu $\checkmark$ Ukraini [The main tendencies of management of tourist activity in Ukraine]. Pidpryiemnytstvo i torhivlia, 20, 5-8 [in Ukrainian].

Herasymenko, V.H, \& Halasiuk, S.S. (2008). Upravlinnia natsionalnym turyzmom v konteksti mizhnarodnoho dosvidu [Managing national tourism in the context of international experience]. Visnyk DITB, 12, 160-167 [in Ukrainian].

Subota, M.V. (2012). Innovatsiini pidkhody do stymuliuvannia rozvytku kurortiv [Innovative approaches to stimulate resort development]. Problems of science, 12, 28-32 [in Ukrainian].

Subota, M.V. (2013). Stratehichni oriientyry derzhavnoi polityky stymuliuvannia rozvytku kurortnoi diialnosti [Strategic guidelines of the state policy of stimulating the development of resort activity]. University Economic Bulletin, 20/2, 353-358 [in Ukrainian].

Tkachenko, T.I. (2009). Stalyi rozvytok turyzmu: teoriia, metodolohiia, realii biznesu [Sustainable tourism development: theory, methodology, business realities] [Monograph]. Kyiv: Kyiv national university of trade and economics [in Ukrainian].

Turystychna diialnist v Ukraini u 2018 rotsi [Tourism in Ukraine in 2018]. (2019). State Statistics Service of Ukraine. Retireved from http://www.ukrstat.gov.ua/operativ/operativ2019/ tyr/tyr_dil/arch_tyr_dil.htm [in Ukrainian].

Verkhovna Rada Ukrainy. (1995). Zakon Ukrainy "Pro turyzm" [Law of Ukraine "On Tourism"] № 324/95-VR vid 15.09.1995. Retireved from https://zakon.rada.gov.ua/laws/ show/324/95-вp [in Ukrainian].

Zakharin, S.V. (2002). Derzhavne rehuliuvannia inozemnoho investuvannia [State regulation of foreign investment]. Finansy Ukrainy, 1, 92-101. [in Ukrainian].

Zakharin, S.V., \& Baikov, M.A. (2015). Formuvannia intelektualnoho kapitalu yak oriientyr upravlinnia komertsiinoiu diialnistiu turystychnoho pidpryiemstva [Formation of intellectual capital as a guide for the management of commercial activity of a tourist enterprise]. Molodyi vchenyi, 9, 50-62 [in Ukrainian].

Zakharin, S.V., Sobol, V.P., \& Melnyk, Yu.R. (2013). Stalyi rozvytok sfery turystychnykh posluh: hlobalni tendentsii, mizhnarodna vzaiemodiia, uroky dlia Ukrainy [Sustainable development of tourism services: global trends, international interaction, lessons for Ukraine]. University Economic Bulletin, 20/3, 297-303 [in Ukrainian]. 


\title{
ORGANIZATIONAL AND ECONOMIC MECHANISM OF STIMULATING THE DEVELOPMENT OF TOURISM, RESORTS AND HOTEL INDUSTRY
}

\author{
Serhii Zakharin \\ Doctor of Economics, Senior Research Fellow; \\ ORCID: 0000-0002-1263-8170; e-mail: z0679330105@gmail.com \\ Kyiv National University of Culture and Arts, Kyiv, Ukraine
}

\begin{abstract}
The state and dynamics of tourism services development in Ukraine are analyzed. The main phenomena and processes in the sphere of tourism are evaluated. Key trends in the development of the tourist services market have been identified. It is stated that the development of tourism and resorts is restrained by an insufficient level of infrastructure development, the inconsistency of establishments of accommodation with world standards, technological backwardness of tourist operators, the imperfection of legal and regulatory support of tourist and resort activity. Due to fluctuations in real incomes of the population in the market of tourist services, corresponding fluctuations in solvent demand are observed, which complicates the planning of tourism enterprises' activity, hotel, and resort activity. It is concluded that these reasons exclude the investment attractiveness of the tourist infrastructure and therefore the proper competitiveness of the entire tourism industry. Some aspects of the mechanism of state support of tourism development in Ukraine are described. The formation's factors of the tourist potential of Ukraine are shown. Priority directions of the state policy of stimulating tourism development are substantiated. Suggestions for the improvement of instruments for supporting the development of tourism are introduced.
\end{abstract}

Keywords: tourism; the sphere of tourism; tourism activity; state tourism policy; state support for tourism development 